suffer from taking bromide in this way, but, on the other hand, it is only too common to see patients suffering from the want of it. -I am, Sir, yours faithfully,

Harley-street, W., Dec. 176h, 1917. Ma urich Cratg.

\section{THE TREATMENT OF EXOPHTHALMIC GOITRE BY X RAYS.}

\section{To the Nditor of THE LANOET.}

SIR.-In your issue of Dec. 15th Lieutenant-Colonel T. P. Dunhill discusses the treatment of exophthalmic goitre from a surgical point of view. In the course of his paperthe fairness and courtesy of which might serve as a model in medical controversy - he makes the following remark:-

"It ought to be possible to obtain some unanimity of observation among men who are working along different lines to the same end. If could see the same cases before and after treatment, or before and after could see the same cases befor

As Lieutenant-Colonel Dunhill does me the honour to refer to me as one of the exponents of the $X$ ray method of treatment, I think that perhaps a few comments on my part may help to bring nearer that mutual understanding for which he hopes.

In the first place, let it be said that the attitude of the surgeon and of the radiologist in approaching a case of exophthalmic goitre is essentially the same. Both admit the necessity of searching for ultimate causes; both know from experience that in the majority of cases, "the manifestations of Graves's disease are the manifestations of excessive and disordered functional activity of the thyroid gland." I say from experience, because the lessening of the amount of the thyroid hormone, either as a result of $\mathrm{X}$ rays to the gland, or from actual surgical removal of thyroid tissue, is nearly always followed by clinical improvement. Ang difference of opinion is therefore limited to a consideration as to the best method of reducing the amount of secretion.

Befure proceeding further, it is necessary to draw a sharp line of distinction between the average case and the resistant case. I use the word "resistant" rather than "severe" or "acate" because some of the most alarming cases readily yield to $\mathrm{X}$ rays, whereas now and then one of - the more ordinary type fails to respond.

(1) When an ambulant case presents itself to the physician for treatment it is, of course, his duty to search for any possible cause and also to prescribe drugs, gland extracts, \&c., according to his experience. He should also consider $\mathrm{X}$ rays, and, as an ultimate possibility, surgery. I do not think it will be claimed by anyone-certainly not by Lieutenant.Colonel Dunhill - that ambulant cases should be operated on forthwith. But is there any reason, apart from questions of convenience and expense, why they should not all be treated by $X$ rays from the beginning? That $X$ rays are beneficial is anmitted by the highest authorities-e.g., by Professor Murray and Dr. Hector Mackenzie. Their use permits the patient to remain at work or play and does not in any way interfere with drug or hormone treatment. There is no risk of burning, and no attempt is made, in the average case, actually to destroy any thyroid tissue. To limit the activity of the gland, and at the same time to bring the type of activity back to normal, is the object aimed at. That, with the technique employed, no permanent deficiency of secretion results, is proved by the fact that the majority of cases are cured and remain healthy, while the remainder relapse into a hyperthyroidic state. That faulty methods may overstep the safe limit is true. The surgeon's knife in unskilled hands may slip. And the $\mathrm{X}$ ray tube is a subtle tool, calling for skill and experience in the user. But it remains broadly true that in the average case no risk is run, and that should an operation subsequeritly prove necessary its success will not have been in any way prejudiced by the $X$ ray treatment. Especially is this so of late-within the past yearwhen the combination of the sinusoidal current with $X$ rays has enabled us greatly to reduce the dose of the latter, without in any way interfering with efficiency as regards banishing symptoms, and with an improvement in the cosmetic effects.

The average ambulant case of exophthalmio goitre should receive $X$ ray treatment from an early date. Definite improvement is often manifest within a month.
(2) Resistant oases. - These are cases which do not respond to the ordinary dosage of $\mathrm{X}$ rays, combined with other suitable medical treatment. The courses open are: (a) To increase the $X$ ray dosage till it nears, or even reaches, the sterilisation point; $(b)$ to remove some of the gland tissue surgically.

The objections to $(a)$ are that permanent thyroid feeding may be necessary, and that absolute safety to the skin cannot be guaranteed. As to $(b)$ the drawback in the past has been the high mortality attendant upon the operation. No radiologist is anxious to treat such cases. If the operation mortality has been so reduced by recent improvements in technique as not to exceed that for, say, appendicitis, then I, for one, am ready to retract what I have hitherto said about surgery in such cases and to recommend it. But I am firmly of opinion that few cases should need surgery if properly treated from the beginning. Ulceration of the cornea, visceral degeneration, and extreme emaciation ought never to occur. If suitable medical and $X$ ray treatment does not produce definite improvement, within a reasonable time operation should be considered, and this period should be reckoned by months rather than by years.

(3) There remains to consider briefly the case with acute onset, where the patient is bedridden from the start. Is such a case to be treated by setting up an $X$ ray installation in the patient's house or by operation? Mach will depend upon the stamina of the victim. If he is in no immediate danger of death, or if it is held that an operation would probably prove fatal, $X$ ravs are indicated. But immediate reduction of thyroid secretion can, of course, be secured only by surgery.

Lieutenant-Colonel Dunhill's paper was a fair and temperate statement from the surgeon's view-point. I trust these remarks by a radiologist may deserve the same epithets and may do something to bring about agreement rather than promote controversy.

I am, Sir, yours faithfully,

Francis Harmamax-Joenson, M.D.

Hariey-street, W., Dec. 2vth, 1917.

\section{CONGENITAL WORD-BLINDNESS.}

\section{To the Editor of THE LANCET.}

SIR,-In the review of my book on "Congenital WordBlindness" in THE LANCET of Dec. 8th there is an error which I wish to correct. Your reviewer states: " He cites in some detail various cases of congenital word-blindness that have come under his notice, in one of which there is a report of the pathological condition." The report of the pathological examinatiou thus referred to is on a case of aoquired wordblindness, to which subject the first chapter of the book is entirely devoted; the report has nothing whatever to do with the cases of congenital word-blindness which are recorded in the subsequent chapters of the book. The insertion of these few lines in your columns will greatly oblige Yours faithfully,

Mentone, France, Dec. 12th, 1917. J J MES HINSHELWOOD.

\section{SUCCESS AND FAILURE IN THE TREAT- MENT OF TUBERCULOSIS.}

\section{To the Editor of THE LANCET.}

SIR,-Dr. Louis Cobbett acknowledges that he cannot by isolation even cut off one source of infection, therefore this measure alone is bound to fail in stamping out the disease. Nevertheless, I agree with him, as I have said, that isolation is necessary, and I have no doubt he will keep urging the authorities to establish the 500,000 beds that will be necessary in Great Britain and Ireland. The tubercle bacillus, at any rate, produces a sufficient degree of immunity to enable at least 85 per cent. of those infected to recover without aid. Pneumococcic pneumonia does not confer a marked degree of immunity in those who recover from it-on the contrary; and yet preventive inoculation is stamping out pneumonia amongst the South African miners.

Dr. Cobbett's hopes for the continued decline of the deathrate from tuberculosis are shown to be chimerical by Karl Pearson's investigations. Those who think that the retardation in the decline of the tuberculosis death-rate is solely due to the war are deceiving themselves. 
Finally, since Dr. Cobbett does not deny that a relative immunity can be produced to the tubercle bacillus by jnoculation with a suitable antigen, which $I$ have shown is all that is necessary, and since he acknowledges isolation will not succeed in cutting off the source of infection, 1 must refuse to allow this measure of preventive inoculation to be side-tracked. - I am, Sir, yours faithfully,

University College, Dublin, Dec. 17th, 1917.

$$
\text { W. M. Crofton, M.D. }
$$

\section{THE LATE DR. ELSIE INGLIS. To the Eaditor of THE LANOET.}

SIR, - In the delightful and appreciative account of Elsie Inglis in your issue of Dec. 8th it is stated that she was brought up in " the strict tenets of the Plymouth Brotherhood." The facts are so much the opposite that it is perhaps worth while stating them. Her family on both sides have always belonged to the Anglican Church, and the atmosphere in which she was brought up was one of the most generous tolerance and of the widest and sanest outlook. Her family history in the religious line explains largely her own wide, sympathetic view of men and nations. She herself was a member of the Church of Scotland. I am, Sir, yours faithfully,

Dec. 21st, 1917. E. H. MoL.

\section{(bbitnaty.}

WILLIAM GILMORE ELLIS, M.D., M.R.C.S., PRTNCIPAL CIVIL MEDICAI OFFICER, BTRATTE SETTLEMENTS.

Dr. Gilmore Ellis, who died after an operation at the General Hospital, Singapore, on Oct. 8th last at the age of 57 years, obtained his medical education at St. Bartholomew's Hospital, London, qualifying in 1882, and taking his M.D. Brussels five years later. After acting for a time as resident medical officer and science master at Wellington College he became surgeon to the Eastern Extension Telegraph Company before settling down to his life's work in mental diseases. His first lunacy appointment was at Banstead, and in 1888 he was selected by the Secretary of State as medical superintendent of the Singapore Asylum, a post which he held for nearly 22 years, until his appointment in 1910 as principal civil medical officer of the Straits Settlements. A seat in the Legislative Council followed shortly after.

Dr. Ellis's long colonial career was one of ceaseless activity. At various times he acted as health officer to the Singapore Municipality and as resident surgeon to the General Hospital. He was one of the original members of the Straits Medical Association, founded in April, 1890, and during the life of that body was a constant contributor of clinical notes and papers. To the Joumal of Mental Science he also contributed many articles of psychological value. During the eight years through which he filled the highest medical post in the colony he showed himself a good administrator as well as an indefatigable worker. Although due to retire on pension, at the outbreak of the war he offered to continue in harness in order to tide over the strain occasioned by the absence of nearly half the medical stafi. This effort was doubtless contributory to his sudden illness and death; and it was no empty form which accorded him a funeral with full military bonours.

Dr. Ellis's widow and two daughters survive him, as well as two sons who hold commissions in the Army and are on active service.

\section{THE SERVICES.}

\section{ARMY MEDICAL SERVICW.}

Lieutenant-Colonels relinquishing the rank of temporary Colonel on re-posting: A. W. Hooper, C.M.G., D.S.O,; M. MacG. Rattray. D.s 0 .

Iient.-Col. F. J. Greig, C.M.G., Reserve of Officers, relinquishes the rank of temporary Colonel on re-posting.

Lieutenant Colonels to be temporary Colonels whilst employed as Assistant Dir ctors if Rieclical Services of Divisions: E. W. W.

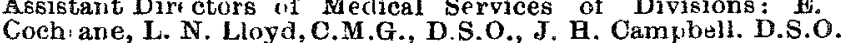

Temporary Colonels to be temp.rary Surgeon-Generals: Sir w. P.

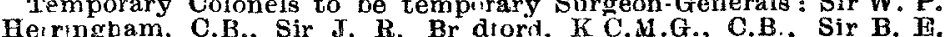
Dawson, K.C.V.O., C.D., C. S. Wallace, C.M.G., Sir B. G. A. Moynihan, O. B.
ROYAL ARMY MEDICAL CORPS.

The undermentioned relinquish the acting rank of Lieutenant. Colone? on re-posting: Major (temporary Lieut, Col.) T. J. Wright, D.S.o. Capt. (temporary Lieut.-Col,) A. Irvine-Fortescue.

Major B. S Burtlett retains the acting rank of Lieutenant-Colonel whilst commandino a Casunlty Clearing station.

Capt. H. A.T. Fairbank, R.A.M.C., T.F, to be temporary LieutenantColonel.

Majors to be acting Lieutenant.Colonels whilst in command of a Medieal Unit: P. C. T. Davy, C.M.G., R. H. Bridges, D.S.().

Major E. T. Potts, D.S O., to be acting Lieutenant-Colonel whilst mployed as Assistant Director of Medical Services of an Army. Major J. H. Grabam is placed iemporarily on the Half-pay List on account of ill-health.

R. F. Kennedy to be temporary honorary Major whilst serving with a. General Hospiral.

J. W. B. Thorburn, late temporary Captain, is granted the honorary rank of Captain.

T'emp. Capt. J. M. Macmillan to be temporary Major.

Temporary Lieutenants to be temporary Captains: R. Cope, J. G. Macqueen, J. C. L. Day, A. Leeming, G. Cooper, C. M urphy, W. $\mathbf{W}$. Burrows. E. W. Milne, S. E. Holder, T. F. M Mrphy, R. C. Corbett, A. Mackillan, A. B. Coomber, S. P. Pullard, C. H. Clay.

To be temporary Honorary Lieutenants: C. R. Bird, G. Lucas, D. E. Carter, A. Gregg, E. B. Fitzgerald, J. E. Bloomer, H. W. Woodward, W. M. Findley.

W. M. Findley. G. Mer. Dale, G. A. MeLarty, J. R. Burn. A. E. MeKibbin. G. M. G. MeI. Dale, G. A. MeLarty, J. R. Burn, A. E. McKibbin. G. M.
Huggins, J. B. Yelf, A. L. H. Rackham ; Temp. Lleut. L. G. Teece Huggins, J. B. Yelf, A, L. H. Rackh
(on account of ill-health), H. S. Viviau.

$$
\text { Canadian Arrny Medieal Corps. }
$$

Temp. Lieut.-Col. J. M. Flder to be temporary Colonel.

Temp. Major A. C. Rankin to be temporary Lientenant-Colonel.

Temp. Capt. (acting Lieut.-Col.) A. Croll to be temporary Major and Temp. Capt. (acting Lieut.-Col.) A. Croll to bo

to retain the acting rank of Lieutenant-Colonel.
Temporary Captains (acting Majors) to be temporary Majors: Temporary Captains (acting Majors) to be temporary Majors
J. J. Ower, R. J. Mefwen, T. F. O'Hagan, M.C., R. H. Smith, S. G. J. J. Ower, R. J. Mctiwen, T. F. O'Hagan, M.C., R. H. Smith, S. G.
Ross, M.C., R. H. M. Hardisty, H. Buck, G. W. Treleaven, H. E. Paul. Temporary Captains to be temporary Majors : R. F. Fleg. Paul. Temporary Captains to be temporary Majors : R. F. Flegg, J. L.
Cock, G. O. Taylor, K. M. Luton, M.C.. J. MeW. Taylor, A. H. Taylor, M.C., W. Brown, M.C., D. McLellan, J. W. Pileher, N. G. Cooper T. L. Butters, G. O. Hale, H. P. Wright, F. S. Ruttan, J. M. Stewart . H. Burnham, H. B. Bıyd, E. D. Hubbell, J. H. M. Bell

Temp. Capt. $\mathrm{C}$. W. Waldron to be acting Major while specially employed.

To be temporary Captains: W. E. Ainley, Temp. Lieut. A. B. Whytock, Temp. Lieut. E. C. A. Orawford.

\section{Canadian Army Dental Corps.}

Temporary Lieutenants to be temporary Captains: F. G. Berry R. H. Aljoe, O. N. Westwood, J. H. Reid, A. G. Fraser (from Western Ontarjo Regiment).

SPECIAL RESERVE OF OFFICERS.

Temp. Capt. D. MeIntyre, from R.A.M.C.. to be Captain. TERRITORIAT FOROE.

Capt. (Brevet Major) R. I. Guthrie to be acting Lieutenant-Colone whilst in command of a Hospital.

Temp. Capts. G. Hollies and J. Lytle to be temporary Majors, Shropshire Medical Volunteer Corps.

R. M. Wilson (late Lieutenant Colonel, R.A.M.O., T.F.), to be Medical Officer and temporary Captain, 1/1st Batt. County of Aberdeen Volunteer Regiment.

Capt. D. McP. Taylor relinquishes his commission on account of ill-health contractea on active service, and is granted the honorary rank of Captain.

Lieut.Cul. (Brevet-Col.) H. W. Webber is restored to the establishment.

Capt. (acting Lieut.-Col.) C. Cameron relinquishes his acting rank on ceasing to command a Field Ambulance.

Capt. H. L. P. Hulbert relinquishes his commission on account of ill-health contracted on active service, and is granted the honorars rank of Captain.

G. T. Giddings to be temporary Major, and R. M. H. Randall and A. C. Haslam to be temporary Captains, Kent Medical Volunteer C. $W$. Pilcher to be temporary Captain, Lincolnshire Medical Volunteer Corps.

TERRITORIAL FORCE RESERVE.

Capt. C. T. Matthews, from Iield Ambulance, to be Captain.

\section{URBAN VITAL STATISTICS.}

(Week ended Dec. 15ch, 1917.)

English and Welsh Towns.-In the 96 English and Welsh towns, with an aggregate civil population estimated at nearly 17,000.000 persons, the annual rate of mortalit $y$ was equal to $13 \cdot 6$, against $11 \cdot 9$ and $12^{\cdot 4}$ per 1000 in the two preceding weeks. In London, with a population exceeding 4,000,000 persons, the death-rate was $13 \cdot 7$, or 0.6 per 1000 above that recorded in the previous week; among the remaining towns the rates ranged from 5.2 in Rochdale, 5.5 in Fdmonton and in Great Yarmouth, and 7.2 in Huddersfield, to 21.4 in Liverpool, 21.9 in stuckton-on-Tees, and 22.4 in South Shields. The principal epidernic diseases caused $376^{\circ}$ deathe, which corresponded to un aunual rate of 1.2 per 1000 , and included 119 from measles, 110 from whooping-cough, 67 from diphtheria, 56 from infantile diar rboea, 17 trom scarlet fever, and 7 from enteric fever. Measles ca used a death-rate of $2 \cdot 7$ in Acton, 3.5 in St. Felens, 4.1 in Leicester and 4.5 in Brigbton, and whooping-cough of 1.6 in Liverpool, 1.9 in Wiyan, and 2.3 in Middlesbrough. The 1330 cases of scariet tever and 1679 of diphtberia under treatment in the Metropolitan Asylums Hospitals and the London Fever Hospital were respectively 21 below and 44 above the numbers remainiug at the end of the previous week. violne deaths from all causes in the 66 towns, 150 resulted trom 